\title{
Antioxidant and anti-fatigue effects of abalone (Haliotis discus hannai) composites containing natural plants
}

\author{
Soo-Jung Lee ${ }^{1}$, Soo-Jeong $\mathrm{Oh}^{2}$, Min-Jung Kang ${ }^{3}$, Jung-Hye Shin ${ }^{3}$, Shin-Kwon Kang ${ }^{4 *}$ \\ ${ }^{1}$ Institute of Agriculture and Life Sciences, Gyeongsang National University, Jinju 52828, Korea \\ ${ }^{2}$ Institute of Hadong Green Tea, Hadong 52304, Korea \\ ${ }^{3}$ Namhae Garlic Research Institute, Namhae 52430, Korea \\ ${ }^{4}$ Department of Food Medicinal, International University of Korea, Jinju 52833, Korea
}

\section{전복 복합물의 항산화능 및 피로개선 효과}

\author{
이수정 ${ }^{1} \cdot$ 오수정 ${ }^{2} \cdot$ 강민정 $^{3} \cdot$ 신정혜 $^{3} \cdot$ 강신권 $^{4 *}$ \\ ${ }^{1}$ 경상대학교 농업생명과학연구원, ${ }^{2}($ 재 $)$ 하동녹차연구소, \\ ${ }^{3}($ 재 $)$ 남해마늘연구소, ${ }^{4}$ 한국국제대학교 식품의약학과
}

\begin{abstract}
To develop a functional drink using abalone, two abalone composites (APM-1, APM-2) were prepared by mixing the abalone and natural plants (Lycii fructus and Rubus coreanus Miq.). Their antioxidant and anti-fatigue effects were evaluated using rats running on a treadmill after 4 weeks supplementation of the abalone composites. Experimental groups were divided into four groups including normal (non-exercised group), control (exercised group), one dose per day (EAPM-1), and three doses per day (EAPM-2) with exercise by running. Antioxidant activities, and total phenols and flavonoids contents of APM-2 were significantly higher than those of APM-1 (p<0.05). Total lipid content in serum of EAPM-2 was significantly lower than that of control group $(p<0.05)$. Lactate dehydrogenase activity and blood urea nitrogen content of EAPM-1 and EAPM-2 groups were significantly lower than that of control group. There were no significant difference in aspartate aminotransferase activity among control, EAPM-1 and EAPM-2 groups. In the meanwhile, alanine aminotransferase and alkaline phosphatase activities were significantly lower than that of control group. In serum and liver tissues of EAPM-1 and EAPM-2 groups, lipid peroxide contents significantly decreased compared to control group. DPPH radical scavenging activities in liver tissues of EAPM-1 and EAPM-2 groups were significantly higher than those of control group. Therefore, abalone composites were effective for the alleviation of oxidative stress caused by treadmill running, which was dependent on antioxidant activity and phenolic compounds content.
\end{abstract}

Key words : abalone composites, anti-fatigue, antioxidant, LDH activity, lipid peroxide

\section{서 론}

현대인은 신체 운동이나 과다한 노동 및 복잡한 일상생 활에서 초래되는 스트레스로 신체기능의 저하, 체내 균형

*Corresponding author. E-mail : hito56@naver.com

Phone : 82-55-751-8321, Fax : 82-55-751-8329

Received 20 May 2015; Revised 7 July 2015; Accepted 10 July 2015.

Copyright (c) The Korean Society of Food Preservation. All rights reserved.
파괴, 피로물질의 축적과 이로 인한 만성적인 증상 등의 다양한 생리현상으로 표출되는 피로에 지속적으로 노출되 기 쉽다(1). 특히 운동은 유형에 따라 인체에 미치는 영향이 다른데, 적절한 운동은 근육에 방어 시스템을 활성화 시키 고, 유리 라디칼에 의한 손상 감소, 폐의 공기 정화를 증대시 켜 대사를 원활하게 한다. 반면에 과도한 탈진적 운동은 다량의 에너지를 소비함으로써 산화적 스트레스를 초래하 거나 지질과산화물의 축적, 체내 저장 영양소의 감소로 혈 액 순환과 체온의 변화 등을 일으키는 원인이 되므로 인체 는 오히려 자기 방어를 위해 소모된 에너지원을 보충하고, 
축적된 대사물의 제거와 신체변화를 개선하기 위해 휴식과 영양보충을 필요로 한다(2). 따라서 에너지를 빠르게 보충 할 수 있는 식품이나 영양소의 섭취는 인체에 무리를 주지 않으면서 직·간접적으로 피로회복에 긍정적인 효과를 나타 내므로 최근 현대인의 만성적인 피로회복을 위한 기능성 식품에 대한 요구도가 점진적으로 높아지고 있다.

전복(Haliotis discus hannai)은 바닷물이 깨끗한 곳에서 해조류를 주된 먹이로 하는 원시복족목(Archaeogastropoda) 전복과에 속하는 복조류의 수산생물이다. 조개류 중 수분 함량이 많으며, 저열량, 고단백 식품으로 철분, 타우린, 비 타민 $\mathrm{B}_{1}, \mathrm{~B}_{2}$, 칼슘, 인 등의 영양소가 풍부한 건강식으로 피부미용, 자양강장 등에 효능이 있을 뿐 아니라, 특히 타우 린이 풍부하여 간 보호, 피로회복, 심근경색에 대한 예방효 과를 가지고 있어 영양면이나 맛이 우수한 것으로 알려져 있다(3). 이리하여 오래 전부터 우리나라, 중국 및 일본 등지 에서 상당히 귀하게 여기는 수산물로 시장 가치가 매우 높게 평가되고 있다(4). 전복은 기능성 측면에서 전복 추출 물에서 혈압강하, 항산화 기능 및 항혈전능이 보고된 바 있으며(3), 전복의 세포내 활성산소종 억제를 이용한 항산 화 활성(5), 천연식물류와의 복합물에서 항산화 및 알콜대 사 활성 등에 효과가 있었다는 보고가 있다(6).

이와 같이 전복이 영양 및 기능성 면에서 여타의 수산물 에 비해 우수한 것으로 인지되고는 있으나, 국내의 전복 생산은 대부분 양식에 의존적이며, 양식 과정 중 일정 기간 이 지나도 더 이상 크기가 자라지 않는 열성패의 생산이 불가피하므로 크기가 작은 열성패는 생전복으로서의 부가 가치가 매우 낮은 실정이다. 더욱이 전복은 희소성의 가치 로 인하여 가공식품 제조와 관련한 기술이 거의 없으며, 대부분이 저장성이 확보되며 한방 약재로 활용하기 위한 건조품 가공에 제한되어 있는 실정이다.

본 연구에서는 전복 열성패의 활용도 및 부가가치 향상 을 위하여 음료를 제조하였으며, 전복 자체의 비린맛 개선 및 기능성 증대를 위하여 항산화 활성이 있는 천연 식물류 를 첨가하여 피로회복 및 항산화 기능이 향상된 전복 음료 를 개발하고자 하였다. 예비실험 결과에서 선정된 항산화 활성 및 기호성이 높은 전복 복합물을 트레드밀 운동한 흰쥐에 급이하므로써 생체 내 성분 변화를 분석하여 기능성 전복 음료로써 활용 가능성을 평가하였다.

\section{재료 및 방법}

\section{전복 복합물의 제조}

전복은 활전복을 구입하여 빙장한 상태로 실험실로 옮긴 후 즉시 껍질을 제거하고 흐르는 수도수에 가볍게 세척하여 실온에 20 분간 정치하여 표면의 물기를 제거한 후 세절하 였다. 그 외 천연식물류는 한약 재료상에서 건조상태의 국
내산 원료를 구입하였다. 세절한 전복 $120 \mathrm{~g}$ 에 구기자 $(20$ $\mathrm{g})$, 복분자 $(20 \mathrm{~g})$, 배 농축액 $\left(69^{\circ} \mathrm{Brix}, 10 \mathrm{~g}\right)$, 생강 $(10 \mathrm{~g})$, 감초 $(6 \mathrm{~g})$, 마늘 $(6 \mathrm{~g})$, 계피 $(4 \mathrm{~g})$ 및 대추 $(4 \mathrm{~g})$ 를 혼합한 시료(200 $\mathrm{g}$ )에 대해 10 배의 물을 첨가하여 $100^{\circ} \mathrm{C}$ 에서 6 시간 환류냉각 하여 추출한 후 여과하였다. 이를 진공 농축하여 전복 복합 물의 고형물 함량을 $6 \%$ 로 조정하였으며, $120 \mathrm{~mL}$ 로 레트로 트 파우치 포장한 것을 성인(체중 $70 \mathrm{~kg}$ )에 대한 1 회 분량으 로 하였다.

\section{전복 복합물의 항산화능 및 유효성분의 측정}

전복 복합물의 1,1-diphenyl-2-picrylhydrazyl(DPPH) 라 디칼 소거능은 시료액에 $0.08 \% \mathrm{DPPH}$ 용액을 동량으로 혼 합하여 실온에서 반응시킨 다음 $517 \mathrm{~nm}$ 에서 시료 무첨가구 를 대조로 하여 흡광도를 측정하였다(7). 2,2'-azinobis-(3ethylbenzo-thiazoline-6-sulfonate)(ABTS) 라디칼 소거능은 $7 \mathrm{mM}$ ABTS 용액에 potassium persulfate를 $2.4 \mathrm{mM}$ 이 되도 록 용해한 뒤 암실에서 12시간 이상 반응시킨 후 $415 \mathrm{~nm}$ 에 서 1.5 가 되도록 흡광도를 조정한 ABTS 기질용액에 시료액 을 혼합하여 반응시킨 다음 시료 무첨가구를 대조로 하여 흡광도를 측정하였다(8). DPPH 및 ABTS 라디칼 소거능은 시료 무첨가구에 대한 시료 첨가구의 흡광도비(\%)로 계산 하였다. Ferric-reducing antioxidant potential ability(FRAP) 법에 의한 환원력은 시료액 $40 \mu \mathrm{L}$, 증류수 $40 \mu \mathrm{L}, \mathrm{FRAP}$ 기질용액 $100 \mu \mathrm{L}$ 를 차례로 혼합하여 $37^{\circ} \mathrm{C}$ 에서 4 분간 반응 시켜 $593 \mathrm{~nm}$ 에서 흡광도를 측정하였으며, $\mathrm{FeSO}_{4} \cdot 7 \mathrm{H}_{2} \mathrm{O}$ 를 표준물질로 하여 작성한 검량선에 따라 계산하였다(9).

유효성분으로 총 페놀 함량은 전복 복합물을 증류수에 용해하여 Gutfinger(10)의 방법에 따라 측정하였으며, caffeic acid(Sigma-Aldrich Co., St. Louis, MO, USA)를 표준 물질로 한 검량선으로 계산하였다. 플라보노이드 함량은 상기의 전복 복합물을 사용하여 Moreno 등(11)의 방법에 따라 측정하여 quercetin(Sigma-Aldrich Co.)에 의한 검량선 으로 계산하였다.

\section{실험동물 및 사육 조건}

실험동물은 생후 4주령(체중 90 100 g)의 Sprague Dawley계 수컷 흰쥐를 (주)코아텍(Pyeongtaek, Korea)로부터 구입하여 경상대학교 동물실험윤리위원회의 승인(GNU140730-R0032)후 1주일간 조사료로써 예비사육하였다. 사 육은 rat용 사육상자 $(50 \times 30 \times 25.5 \mathrm{~cm})$ 에 2 마리씩 사육하였 으며, 사육실의 온도는 $22.0 \pm 1.0^{\circ} \mathrm{C}$, 상대습도는 $50 \pm 10 \%$ 로 조절하였으며, 명암주기는 12 시간 간격으로 유지하였다. 예비사육 후 난괴법에 의해 각 군의 체중이 비슷하도록 6마리씩 4군으로 나누어 4주간 실험 사육하였다. 정상군(비 운동군, normal) 및 운동대조군(control)은 AIN-93G diet에 의한 normal diet를 급이하였으며, 전복 복합물의 급이량은 성인의 섭취량을 기준으로 하여 실험동물의 체중으로 환산 
하여 운동+전복 복합물 1 일 1 회분 $(0.2 \mathrm{~mL} / 100 \mathrm{~g}$ b.w., APM-1) 급이군을 EAPM-1, 운동+전복 복합물 3 회분(0.6 $\mathrm{mL} / 100 \mathrm{~g}$ b.w., APM-2) 급이군을 EAPM-2로 하였다. 사육 기간 동안 물과 식이는 자유 급이하였다.

\section{트레드밀에 의한 유산소 운동 조건}

실험식이를 4주간 급이하는 동안 소동물용 트레드밀 (XTG910K, SPG Co., Ltd., Anyang, Korea)을 이용하여 매일 오전 10 시에 유산소성 운동부하 훈련을 4 주간 실시하였다. 운동을 시작한 1 주에는 경사도 없이 $15 \mathrm{~m} / \mathrm{min}$ 의 속도로 주행시켰으며, 2 주째에는 $15^{\circ}$ 의 경사도에서 $18 \mathrm{~m} / \mathrm{min}, 3 \sim 4$ 주에는 $25 \mathrm{~m} / \mathrm{min}$ ( $15^{\circ}$ 의 경사도)로 1 일 20 분씩 주 5 회 수행 하였다.

\section{체중 변화, 식이섭취량 및 식이효율 측정}

실험동물의 체중은 주 1 회 일정시간에 측정하였으며, 사 육기간 동안 식이는 매일 오후 5시에 급이하여 다음날 오전 10 시경에 잔량을 조사하므로써 1 일 식이섭취량을 산출하 였다. 1 일 평균 식이섭취량은 실험사육 4 주간의 총 식이섭 취량 $(\mathrm{g})$ 을 총 실험일수(day)로 나누어 계산하였으며, 식이 효율(food efficiency ratio, FER)은 동일기간 동안 체중 증가 량을 총 식이섭취량으로 나누어 산출하였다.

\section{실험동물의 처리}

16 시간 절식시킨 실험 최종일에 $25 \mathrm{~m} / \min \left(15^{\circ}\right.$ 경사도)에 서 트레드밀에 의한 운동을 20 분간 시킨 다음 zoletil 50 (Virbac, Carros, France)을 주사하여 (30 mg/kg b.w.) 마취 가 완료된 것을 확인한 후 심장채혈하였다. 혈액은 빙수 중에 30 분간 정치한 후 $980 \times \mathrm{g}$ 에서 15 분간 원심분리(Mega 17R, HANIL, Incheon, Korea)하여 혈청을 분리하였으며, 간장, 심장, 신장, 비장 및 고환을 차례로 적출하여 생리식염 수로 혈액을 씻은 다음 흡수지로 물기를 제거하고 중량을 측정하였으며, 간조직은 액체 질소로 급냉동한 후 $-70^{\circ} \mathrm{C}$ 에 보관하여 분석에 사용하였다.

\section{혈 액 성분 분석}

혈청 지질성분으로 총 지질 함량은 Frings 등(12)의 방법 에 따라 혈청 $20 \mu \mathrm{L}$ 을 진한 황산으로 분해시킨 후 phosphovanillin 시약을 혼합하여 $37^{\circ} \mathrm{C}$ 에서 15 분간 반응시킨 다음 시료 무첨가구를 대조로 하여 $540 \mathrm{~nm}$ 에서 흡광도를 측정하 였으며, 표준물질로 olive oil을 이용한 검량선에 따라 계산 하였다. 총 콜레스테롤, 중성지방 및 $\mathrm{HDL}$-콜레스테롤 함량 은 효소법에 의한 정량용 kit(Asan pharm. Co., Seoul, Korea) 시약으로 측정하였다. 혈청 LDL-C(low density lipoprotein cholesterol) 함량은 혈청 total cholesterol-(HDL-C + triglyceride/5)의 계산식에 의해 산출하였다(13). 혈중 lactate dehydrogenase(LDH) 활성도, 크레아틴 및 혈중 요소 질소(blood urea nitrogen, BUN) 함량은 전혈을 헤파린 튜브 (FUJI FILM Co., Tokyo, Japan)에 취하여 $980 \times \mathrm{g}$ 에서 15 분간 원심분리한 후 혈액분석기(FUJI DRI-CHEM NX500i, FUJIFILM Co., Tokyo, Japan)로 측정하였다.

\section{간 기능 지표효소 활성 측정}

간 기능 평가를 위한 혈중 지표로써 aspartate aminotransferase(AST) 및 alanine aminotransferase(ALT)활 성 측정은 각각의 kit(AM 101-k, Asan Pharm. Co., Seoul, Korea) 시약으로 측정하였다. Alkaline phosphatase(ALP) 활 성도는 상기의 전혈을 사용하여 혈액분석기로 측정하였다.

\section{혈청 및 간 조직의 지질과산화물 함량 측정}

혈청의 지질과산화물 함량은 혈청 $100 \mu \mathrm{L}$ 에 $1 / 12 \mathrm{~N}$ 황산 용액 및 $10 \%$ phosphotungstic acid를 혼합하여 $1,100 \times \mathrm{g}$ 에서 10 분간 원심분리시켜 침전물을 얻었다. 여기에 증류수 및 thiobarbituric acid(TBA)시약을 각각 $1 \mathrm{~mL}$ 씩 혼합하고 $95^{\circ} \mathrm{C}$ 수옥상에서 1 시간 반응시킨 후 butanol을 가하여 발색물질 을 이행시켜 $532 \mathrm{~nm}$ 에서 흡광도를 측정하였다(14). 간 조직 의 지질과산화물 함량은 $1.5 \% \mathrm{KCl}$ 용액을 첨가한 $10 \%$ 의 간 조직 균질액에 $3 \mathrm{~mL}$ 의 $1 \%$ phosphoric acid 및 $1 \mathrm{~mL}$ 의 $0.6 \% \mathrm{TBA}$ 시약을 혼합한 후 $95^{\circ} \mathrm{C}$ 수옥상에서 45 분간 반응 시켰다. 이때 생성된 발색물질을 butanol에 이행시켜 흡광 도 $\left(\mathrm{OD}_{535-520}\right)$ 를 측정하였으며 지질과산화물 함량은 $1,1,3,3-$ tetra-ethoxypropane으로 작성한 검량선으로 산출하였다 (15).

\section{혈청 및 간 조직의 $\mathrm{DPPH}$ 라디칼 소거능 측정}

혈청에서 라디칼 소거능은 혈청 $100 \mu \mathrm{L}$ 에 $100 \mathrm{mM}$ Tris-HCl 완충액(pH 7.4) 및 $0.01 \% \mathrm{DPPH}$ 용액 $1 \mathrm{~mL}$ 를 가한 다음 실온의 암실에서 20 분간 반응시켰다. 간 조직의 라디 칼 소거능은 상기의 $10 \%$ 간 조직 균질액 $100 \mu \mathrm{L}$ 에 $\mathrm{pH}$ 7.4의 $100 \mathrm{mM}$ tris- $\mathrm{HCl}$ 완충액 $1 \mathrm{~mL}$ 및 $0.01 \% \mathrm{DPPH}$ 용액 1 $\mathrm{mL}$ 를 혼합한 후 실온에서 20 분간 반응시켰다. 그 후 chloroform $4 \mathrm{~mL}$ 를 가하여 진탕 혼합한 다음 $2,800 \times \mathrm{g}$ 에서 10 분간 원심분리시켜 chloroform층을 회수하여 $517 \mathrm{~nm}$ 에 서 흡광도를 측정하였으며, 시료 첨가구와 무첨가구의 흡 광도 비(\%)로 계산하였다(16).

\section{통계 분석}

본 실험결과는 SPSS package(12.0, SPSS Inc., Chicago, $\mathrm{IL}, \mathrm{USA})$ 를 이용하여 평균과 표준편차로 나타내었으며, 통계적 유의성은 Student-t test 및 일원배치 분산분석 (one-way analysis of variance)을 한 후 $p<0.05$ 수준에서 Duncan's multiple range test로 비교분석을 하였다. 


\section{결과 및 고찰}

\section{전복 복합물의 항산화능 및 유효성분}

전복 복합물의 항산화능 및 관련된 유효성분 함량을 측 정한 결과는 Table 1 과 같다. 성인 기준으로 1 일 1 회 섭취량 (APM-1)과 1일 3회 섭취량(APM-2)에 해당되는 전복 복합 물을 대상으로 DPPH, ABTS 라디칼 소거능 및 FRAP법에 의한 환원력을 비교한 결과, APM-1에 비해 APM-2가 유의 적으로 활성이 높았으며, $\mathrm{DPPH}, \mathrm{ABTS}$ 라디칼 소거능은 각각 $1.9,1.5$ 배, FRAP법에 의한 환원력은 2.3 배 높은 활성 이었다. 항산화능 관련 유효성분인 총 페놀 및 플라보노이 드 함량도 APM-1에 비해 APM-2가 약 3배 정도 높은 수준 이었다.

Table 1. Antioxidant activities, total phenol and flavonoids contents in the abalone composites

\begin{tabular}{lcc}
\hline & APM- $1^{1)}$ & APM-2 ${ }^{2)}$ \\
\hline DPPH radical scavenging (\%) & $24.16 \pm 3.51$ & $46.30 \pm 0.46^{*}$ \\
ABTS radical scavenging (\%) & $60.05 \pm 8.80$ & $87.37 \pm 7.05^{*}$ \\
FRAP assay $(\mu \mathrm{M})^{3)}$ & $62.08 \pm 12.60$ & $144.48 \pm 5.39^{*}$ \\
$\begin{array}{l}\text { Total phenol content } \\
\text { (caffeic acid eq. mg/day diet) }\end{array}$ & $1.10 \pm 0.02$ & $3.29 \pm 0.05^{*}$ \\
$\begin{array}{c}\text { Flavonoid content } \\
\text { (quercetin eq. mg/day diet) }\end{array}$ & $0.32 \pm 0.00$ & $0.97 \pm 0.01^{*}$ \\
\hline
\end{tabular}

${ }^{1)}$ APM-1: once fed amount per day from the composite of abalone and natural plants. ${ }^{2)} \mathrm{APM}-2$ : three times fed amount of APM-1.

${ }^{3)}$ Equivalent content of $\mathrm{FeSO}_{4} \cdot 7 \mathrm{H}_{2} \mathrm{O}$.

"This superscripts are significantly different between the different samples by Student $\mathrm{t}$-test at $\mathrm{p}<0.05$

배합비를 달리한 천연식물류에 전복을 혼합한 경우에 총 페놀 함량은 9.21 28.55 mg/100 g의 범위로 식물류의 배합조건에 따라 상이하였으며, DPPH 라디칼 소거능 및 환원력은 시료 중의 총 페놀 함량에 의존적이었는데, 혼합 물을 구성하는 천연식물류 각각의 기능성 차이 때문인 것으 로 보고된 바 있다(6). 이는 한약재의 조성을 달리한 혼합물 에서 항산화능의 차이가 혼합물을 구성하는 특정 재료에
의존적이라는 보고(17)와도 일치하는 결과라 생각된다. 여 러 식물류의 혼합물에서 항산화능은 혼합된 시료간의 시너 지 효과에 의한 것으로(17) 여러 식물류가 혼합되어 추출될 경우 활성이 더욱 증가된다는 보고(18)는 본 연구 결과와 유사한 것으로 사료되며, 전복, 구기자 및 복분자 등으로 구성된 복합물은 시료 자체의 in vitro 항산화능에 의존하여 체내 항산화 활성에도 효과적일 것으로 추정된다.

\section{체중변화, 식이섭취량 및 식이효율}

트레드밀 운동에 의해 산화적 스트레스를 유발한 흰쥐에 게 전복 복합물을 4 주간 급이하는 동안 체중변화, 식이섭취 량 및 식이효율을 측정한 결과는 Table 2 와 같다. 실험사육 4 주 후 최종 체중 및 실험사육 기간 동안의 체중 증가량은 모든 실험군 간에 유의차가 없었다. 1 일 식이섭취량은 대조 군에 비해 EAPM-1군이 유의적으로 낮았으나, EAPM-2군 에서는 유의적으로 높았다. 식이효율은 대조군에 비해 EAPM-1군에서 유의적으로 높았다. 트레드밀 운동 시 헛개 나무 과병 추출물을 급이한 실험쥐에서 운동 유무에 따른 체중 변화는 유의차가 없었으며(19), 트레드밀 운동에 대한 흑마늘과 개똥쑥 추출물의 경구투여 시에도 실험동물의 체중 변화에는 유의차를 보이지 않아(20) 본 연구와 유사한 결과였다.

4주간의 트레드밀 운동은 실험동물의 체중 증감 및 식이 섭취량 변화에 유의적인 영향을 미치지 않았다. 운동 시 전복 복합물의 급이는 성인 기준 1 일 1 회 섭취량으로 설정 된 EAPM-1군에서 식이섭취량이 다소 낮은 반면, 식이효율 은 증가된 경향으로 1 일 1 회 정도의 전복 복합물 섭취 시 식이효율이 증가되며, 3회 이상 섭취할 경우 식이 효율은 다소 낮아지나 전복 복합물의 다량 섭취로 인한 실험동물의 성장에 유의적인 영향을 주지는 않는 것으로 생각된다.

\section{장기 중량}

트레드밀에 의한 운동으로 산화적 스트레스를 유발시킨 흰쥐에게 전복 복합물을 4 주간 급이한 후 장기의 중량을 측정한 결과는 Table 3 과 같다. 간장, 심장, 신장, 비장 및 고환의 중량은 실험군 간에 유의적인 차이가 없었으나, 간

Table 2. Changes of the body weight, food intake and food efficiency ratio in the rats supplemented abalone composites

\begin{tabular}{lcccc}
\multicolumn{1}{c}{ Groups $^{1)}$} & Normal & Control & EAPM-1 & EAPM-2 \\
\hline Final body weight (g) & $275.67 \pm 9.24^{\text {NS2 }}$ & $281.00 \pm 14.09$ & $283.33 \pm 18.21$ & $280.33 \pm 19.05$ \\
Food intake (g/day) & $19.53 \pm 1.01^{\mathrm{b}}$ & $19.81 \pm 0.83^{\mathrm{b}}$ & $18.14 \pm 0.27^{\mathrm{a}}$ & $20.77 \pm 0.25^{\mathrm{c}}$ \\
Total body weight gain (g/4 weeks) & $203.17 \pm 8.35^{\mathrm{NS}}$ & $208.33 \pm 10.09$ & $210.67 \pm 19.41$ & $204.33 \pm 19.78$ \\
FER $^{3)}(\%)$ & $35.97 \pm 2.68^{\mathrm{a}}$ & $36.30 \pm 1.77^{\mathrm{a}}$ & $40.03 \pm 3.48^{\mathrm{b}}$ & $33.94 \pm 3.54^{\mathrm{a}}$ \\
\hline
\end{tabular}

\footnotetext{
${ }^{1)}$ Normal, non exercised group; Control, exercised group by running on the treadmill; EAPM-1, exercised group by running and APM-1 supplementation; EAPM-2, exercised group by running and APM-2 supplementation.

${ }^{2}$ Values are mean \pm SD $(\mathrm{n}=6)$.

${ }^{\text {arc }}$ Values in a column sharing the same superscript letter are not significantly different at $\mathrm{p}<0.05$

${ }^{\mathrm{NS}}$ Not significant.

${ }^{3)}$ FER (food efficiency ratio) $=$ total body weight gain $(\mathrm{g} / 4$ weeks $) /$ food intake $(\mathrm{g} / 4$ weeks $) \times 100$.
} 
중량은 비운동군(정상군)이 $3.06 \mathrm{~g} / 100 \mathrm{~g} \mathrm{b.w}$.인 반면에 운 동군 $(2.92 \mathrm{~g} / 100 \mathrm{~g} \mathrm{b.w}$.)에서 다소 낮은 경향이었다. 반면에 고환의 중량은 정상군에서 $1.09 \mathrm{~g} / 100 \mathrm{~g}$ b.w.이었는데, 대조 군 및 전복 복합물 급이군에서 $1.14 \mathrm{~g} / 100 \mathrm{~g}$ b.w.으로 유의적 인 차이는 아니었지만 다소 증가된 현상을 보였다.

트레드밀 운동에 의한 실험동물의 장기 중량 변화는 정 상군에 비해 운동군에서 유의적으로 감소되는 경향이었으 나, 운동군에서 헛개나무 과병 추출물의 농도별 급이에 따 른 유의차는 없었다고 보고되어 있다(19). 수영 운동 시 마늘 추출물과 비타민 B군의 급이(21) 및 헛개나무 열매 추출물의 급이에 따른 단위체중당 장기 중량에 대한 유의차 는 없었다고 보고되어(22) 트레드밀 운동이나 수영 운동의 유무가 실험동물의 장기 중량에 유의적인 영향을 주지 않는 것으로 판단된다.

Table 3. The weight of organs and body fat in the rats supplemented abalone composites

\begin{tabular}{ccccc} 
& & & & $(\mathrm{g} / 100 \mathrm{~g}$ b.w. \\
\hline Groups $^{1)}$ & Normal & Control & EAPM- 1 & EAPM- 2 \\
\hline Liver & $3.06 \pm 0.31^{\text {NS2 }}$ & $2.92 \pm 0.18$ & $2.94 \pm 0.21$ & $2.89 \pm 0.38$ \\
Heart & $0.40 \pm 0.04^{\mathrm{NS}}$ & $0.38 \pm 0.02$ & $0.39 \pm 0.03$ & $0.39 \pm 0.03$ \\
Kidney & $0.85 \pm 0.02^{\mathrm{NS}}$ & $0.84 \pm 0.06$ & $0.81 \pm 0.04$ & $0.85 \pm 0.07$ \\
Spleen & $0.27 \pm 0.02^{\mathrm{NS}}$ & $0.27 \pm 0.02$ & $0.26 \pm 0.01$ & $0.27 \pm 0.02$ \\
Testis & $1.09 \pm 0.19^{\mathrm{NS}}$ & $1.14 \pm 0.07$ & $1.14 \pm 0.05$ & $1.14 \pm 0.09$ \\
\hline
\end{tabular}

${ }^{1)}$ Normal, non exercised group; Control, exercised group by running on the treadmill; EAPM-1, exercised group by running and APM-1 supplementation; EAPM-2, exercised group by running and APM-2 supplementation.

${ }^{2)}$ Values are mean $\pm \mathrm{SD}(\mathrm{n}=6)$.

${ }^{\text {NS }}$ Not significant.

\section{혈중 지질 함량 및 심혈관질환 위험도 평가}

트레드밀 운동 시 전복 복합물의 급이에 따른 흰쥐의 혈중 지질 성분 변화를 측정한 결과는 Table 4 와 같다. 총 지질 함량은 대조군에 비해 전복 복합물을 급이한 EAPM-2
군이 유의적으로 감소되었으나, EAPM-1군은 대조군과 유 의차를 보이지 않았다. 총 콜레스테롤, 중성지방, $\mathrm{HDL}-\mathrm{C}$ 및 LDL-C 함량은 모든 실험군간에 유의적인 차이를 보이지 않았다. HDL-C 함량에 대한 총 콜레스테롤 비로 나타내는 심혈관질환 위험도는 대조군에 비해 EAPM-2군에서 다소 낮은 경향이었으나 유의차는 보이지 않았다.

운동과 식품섭취의 병행에 따른 상관관계는 운동의 조건 이나 식품의 종류에 따라 상이한데, 트레드밀 운동한 흰쥐 에서 매실, 오가피, 맥문동의 혼합음료 급이는 혈중 중성지 방 수준을 감소시켰다고 보고된 바 있다(23). 또한 흰쥐의 트레드밀 운동 시 흑마늘 및 개똥쑥의 단일 추출물을 급이 한 경우보다 혼합물을 급이했을 때 혈중 지질 개선에 효과 적이었으며, 혼합물의 농도에 따른 유의차는 없었다고 보 고되어 있다(21). 흑마늘과 5종의 생약재 혼합물을 성인의 체중 기준으로 1 일 1 회분 및 3 회분 섭취량으로 구분하여 간헐적으로 트레드밀 운동한 흰쥐에게 급이한 결과 1 회분 급이군에서는 대조군과 유의차를 보이지 않았으나 3회분 급이군에서는 대조군에 비해 혈중 지질 개선에 유의적인 차이를 보였다는 보고가 있다(24). 또한 자양강장 식품의 4 주간 복용과 2 주간의 수영운동 병행에서 체중감소 현상은 기능성 식품에 의한 효과로 수영운동 시간을 일정하게 제한 할 경우에 운동 대조군과 기능성 식품 급이군간에 유의적인 차이가 있었다는 보고(25)로 볼 때, 적절한 운동과 전복 복합물 섭취의 병행은 혈중 지질 개선에도 도움이 될 것으 로 사료된다.

\section{혈청 $\mathrm{LDH}$ 활성, 크레아틴 및 $\mathrm{BUN}$ 의 함량}

트레드밀 운동으로 산화적 스트레스를 유발한 흰쥐에게 전복 복합물을 4 주간 급이하였을 때 혈청 $\mathrm{LDH}$ 활성, 크레 아틴 및 $\mathrm{BUN}$ 의 함량을 축정한 결과는 Table 5 와 같다. $\mathrm{LDH}$ 활성은 정상군에 비해 대조군에서 유의적으로 높았다. 대 조군에 비해 전복 복합물 급이군은 유의적으로 감소되었 다. 크레아틴 함량은 실험군간에 유의차를 보이지 않았다.

Table 4. Lipid profiles in serum of the rats supplemented abalone composites

\begin{tabular}{lcccc}
\multicolumn{1}{c}{ Groups $^{1)}$} & Normal & Control & EAPM- & EAPM-2 \\
\hline Total lipid (mg/dL) & $330.13 \pm 26.81^{\text {(2) }}$ & $311.88 \pm 46.90^{\text {bc }}$ & $268.64 \pm 26.81^{\text {ab }}$ & $233.09 \pm 19.18^{\mathrm{a}}$ \\
Total cholesterol (mg/dL) & $75.63 \pm 1.57^{\mathrm{NS}}$ & $75.65 \pm 2.92$ & $75.12 \pm 3.43$ & $75.41 \pm 3.48$ \\
Triglyceride (mg/dL) & $38.60 \pm 2.04^{\mathrm{NS}}$ & $37.49 \pm 2.75$ & $35.65 \pm 4.60$ & $34.49 \pm 3.04$ \\
HDL-C (mg/dL) & $26.17 \pm 0.89^{\mathrm{NS}}$ & $27.86 \pm 1.57$ & $26.92 \pm 1.01$ & $27.97 \pm 2.19$ \\
LDL-C (mg/dL) & $41.74 \pm 1.98^{\mathrm{NS}}$ & $38.79 \pm 3.15$ & $41.08 \pm 2.92$ & $39.54 \pm 3.22$ \\
CRF & $2.89 \pm 0.12^{\mathrm{b}}$ & $2.72 \pm 0.10^{\mathrm{ab}}$ & $2.79 \pm 0.05^{\mathrm{ab}}$ & $2.67 \pm 0.16^{\mathrm{a}}$ \\
\hline
\end{tabular}

${ }^{1)}$ Normal, non exercised group; Control, exercised group by running on the treadmill; EAPM-1, exercised group by running and APM-1 supplementation; EAPM-2, exercised group by running and APM-2 supplementation.

${ }^{2)}$ Values are mean $\pm \mathrm{SD}(\mathrm{n}=6)$.

${ }^{a-c}$ Values in a column sharing the same superscript letter are not significantly different at $p<0.05$.

${ }^{\mathrm{NS}}$ Not significant.

${ }^{3)} \mathrm{CRF}$ (cardiac risk factor)=total cholesterol/HDL-cholesterol. 
BUN 함량은 전복 복합물 급이군이 대조군에 비해 유의적 으로 감소되었으며, 이는 정상군과 유사한 수준이었다.

$\mathrm{LDH}$ 는 근육 활동에 의해 근세포 내에서 젖산의 생성과 대사를 조절하므로 운동에 따른 피로회복과 조직손상의 지표로 알려져 있다(26). 본 실험에서 혈중 $\mathrm{LDH}$ 활성은 정상군에 비해 운동군에서 유의적으로 증가되었으며, 전복 복합물의 급이로 감소되는 경향이었다. 강제 수영한 실험 동물에 헛개나무 열매의 열수 추출물 급이는 수영 운동군에 비해 $\mathrm{LDH}$ 활성을 감소시켰는데, $200 \mathrm{mg} / \mathrm{kg}$ b.w. 급이군이 $100 \mathrm{mg} / \mathrm{kg}$ b.w. 급이군보다 유의적인 감소를 보였다고 보고 되어 있다(22). 또한 트레드밀 운동한 흰쥐에서 헛개나무 과병 열수 추출물의 급이는 100 및 $200 \mathrm{mg} / \mathrm{kg} \mathrm{b.w}$. 급이군 모두 운동군에 비해 유의적인 감소를 보였다는 보고도 있다 (19).

크레아틴은 근육운동에 의한 손상 발생 및 지연에 관한 지표로 트레드밀 운동한 실험동물은 비운동군과 비교하여 크레아틴 함량에 유의차가 없었으며, 운동과 함께 헛개나 무 과병 추출물의 병행급이 시에도 운동군에 비해 유의적인 차이를 보이지 않은 것으로 보고되어 있다(19). 한편 아미노 산의 탈아미노 과정에 의해 생성되는 BUN은 간에서 합성 되어 신장으로 배설되는데, 신장의 사구체 여과율이 감소 될 경우 체내 BUN 함량이 증가하게 된다(27). 이와 같이 단백질 대사이상을 나타내는 지표로 활용되는 혈중 $\mathrm{BUN}$ 함량의 정상 수준은 5 23 mg/dL로 알려진 바(28), 본 실험 결과에서 모든 실험군이 정상 범위에 해당되었으나, 전복 복합물의 급이에 따른 BUN 감소 현상은 시료 중의 항산화 성 물질에 의한 세포 보호 효과에 의한 결과라 추정된다.
인삼, 맥문동, 오미자, 녹차, 마늘로 처방된 원기생맥산의 물 및 에탄올 추출물을 강제 수영한 실험동물에 급이하였을 때 에탄올 추출물 급이군에서 대조군에 비해 유의적으로 $\mathrm{LDH}$ 활성 및 $\mathrm{BUN}$ 함량이 감소되었으며, 이러한 현상이 시료 중의 총 페놀 함량에 의존하여 항산화능이 높았기 때문이라고 고찰된 바 있다(29). 따라서 전복 복합물의 섭취 는 운동으로 증가될 수 있는 혈중 $\mathrm{LDH}$ 수준을 감소시킴으 로써 운동에 요구되는 에너지 손실을 방지하며, 피로물질 의 체내 축적을 감소시킴으로써 근육 피로를 줄이는데 도움 이 되며, 이러한 기작은 일상생활로부터 초래되는 스트레 스의 경감에도 유사하게 작용될 것으로 사료된다.

\section{AST, ALT 및 ALP 활성}

강제적인 트레드밀 운동한 흰쥐에 전복 복합물의 급이 시 혈중 $\mathrm{AST}, \mathrm{ALT}$ 및 $\mathrm{ALP}$ 활성에 미치는 영향을 측정한 결과는 Table 6과 같다. 정상군에 비하여 AST 및 ALP 활성 은 대조군이 유의적으로 증가하였으나, ALT 활성은 유의 차가 없었다. AST 활성은 대조군과 전복 복합물 급이군간 에 유의차가 없었으며, ALT 및 ALP 활성은 대조군에 비해 전복 복합물 급이 시 유의적으로 감소되었다.

본 연구에서 트레드밀 운동 유무에 따른 흰쥐의 AST 활성은 유의적으로 상승되었으나, ALT 활성은 유의차가 없었는데, 헛개나무 과병 열수 추출물의 급이는 운동군에 비해 혈중 AST 및 ALT 활성을 유의적으로 감소시켜 시료 의 급이가 혈중 간 기능 효소활성 감소에 관여하는 것으로 보고되어 있다(19). 따라서 운동 시 전복 복합물의 급이는 운동에 의해 증가된 $\mathrm{AST}$ 및 $\mathrm{ALP}$ 활성을 감소시키는데

Table 5. LDH, creatine and BUN contents in serum of the rats supplemented abalone composites

\begin{tabular}{lcccc}
\hline \multicolumn{1}{c}{ Groups $^{1)}$} & Normal & Control & EAPM- & EAPM-2 \\
\hline LDH (U/L) & $1817.75 \pm 527.69^{\mathrm{b} 2)}$ & $2414.75 \pm 426.34^{\mathrm{c}}$ & $1680.25 \pm 139.76^{\mathrm{ab}}$ & $1166.75 \pm 138.89^{\mathrm{a}}$ \\
Creatine (mg/dL) & $0.33 \pm 0.05^{\mathrm{NS}}$ & $0.40 \pm 0.00$ & $0.38 \pm 0.05$ & $0.35 \pm 0.06$ \\
BUN (mg/dL) & $18.53 \pm 2.13^{\mathrm{a}}$ & $22.23 \pm 3.73^{\mathrm{b}}$ & $17.98 \pm 0.99^{\mathrm{a}}$ & $15.45 \pm 0.93^{\mathrm{a}}$ \\
\hline
\end{tabular}

${ }^{1)}$ Normal, non exercised group; Control, exercised group by running on the treadmill; EAPM-1, exercised group by running and APM-1 supplementation; EAPM-2, exercised group by running and APM-2 supplementation.

${ }^{2)}$ Values are mean $\pm \mathrm{SD}(\mathrm{n}=6)$.

${ }^{\mathrm{a}-\mathrm{c}}$ Values in a column sharing the same superscript letter are not significantly different at $\mathrm{p}<0.05$.

${ }^{\mathrm{NS}}$ Not significant.

Table 6. AST, ALT and ALP activities in serum of the rats supplemented abalone composites

\begin{tabular}{lcccc}
\hline \multicolumn{1}{c}{ Groups $^{\mathrm{l}}$} & Normal & Control & EAPM-1 & EAPM-2 \\
\hline AST (Karmen unit/mL) & $65.25 \pm 3.59^{\mathrm{a}}$ & $86.00 \pm 3.92^{\mathrm{b}}$ & $75.75 \pm 13.25^{\mathrm{ab}}$ & $83.25 \pm 5.56^{\mathrm{b}}$ \\
ALT (Karmen unit/mL) & $5.30 \pm 0.42^{\mathrm{bc}}$ & $5.98 \pm 0.21^{\mathrm{c}}$ & $4.93 \pm 0.79^{\mathrm{b}}$ & $4.00 \pm 0.41^{\mathrm{a}}$ \\
ALP (K-A unit/mL) & $570.75 \pm 58.06^{\mathrm{a}}$ & $691.50 \pm 107.65^{\mathrm{b}}$ & $514.25 \pm 55.37^{\mathrm{a}}$ & $477.75 \pm 60.21^{\mathrm{a}}$ \\
\hline
\end{tabular}

\footnotetext{
${ }^{1)}$ Normal, non exercised group; Control, exercised group by running on the treadmill; EAPM-1, exercised group by running and APM-1 supplementation; EAPM-2, exercised group by running and APM-2 supplementation.

${ }^{2)}$ Values are mean $\pm \mathrm{SD}(\mathrm{n}=6)$.

${ }^{a-c}$ Values in a column sharing the same superscript letter are not significantly different at $\mathrm{p}<0.05$.
} 
도움이 되며, 더욱이 전복 복합물의 1 일 3 회분 섭취 수준의 경우에도 간 기능 효소활성에 두드러진 영향을 주지 않으므 로 전복 복합물을 1 일 3 회까지 섭취하여도 무방하리라 생 각된다.

\section{혈액과 간 조직의 지질과산화물 함량 및 라디칼 소거능}

트레드밀 운동 시 전복 복합물의 급이가 흰쥐의 체내 지질과산화물 생성 및 라디칼 소거능에 미치는 영향을 측정 한 결과는 Table 7과 같다. 지질과산화물 함량은 혈액에서 정상군에 비해 대조군이 유의적으로 증가되었으며, 대조군 에 비해 전복 복합물 급이군에서는 유의적인 감소를 보였 다. 간 조직도 혈액과 유사한 경향이었으나, EAPM-1군에 서만 대조군에 비해 유의적으로 감소하였다. 라디칼 소거 능은 혈액에서 실험군간에 유의차가 없었으나, 간 조직에 서는 대조군에 비해 전복 복합물의 급이군에서 유의적으로 증가하는 경향이었다.

운동으로 인한 산화적 스트레스 발생과 항산화 물질의 섭취 관계에서 폴리페놀 화합물의 함량이 많은 시료를 급이 한 실험군에서 체내 지질과산화물 생성저해에 효과적이었 다는 보고가 있다(30). 고강도로 운동시킨 실험쥐에서 흑마 늘 추출물의 급이는 체내 지질과산화물의 생성 감소에 효과 적이었는데(31), allium속 식물류에 함유된 플라보노이드 가 체내 항산화능 증가 및 유리 라디칼의 소거제로써 체내 과산화지질 생성을 저해함으로써 조직 보호 효과에 관여하 는 것으로 알려져 있다(32). 전복은 in vitro에서 혈압 강하 및 항산화능이 있으며, 간장 보호, 피로회복, 심근경색 예방 효과를 내는 타우린의 함량이 풍부하다고 알려져 있으나, 이들 성분과 전복의 항산화능과 직접적인 관련성은 적다고 보고되어 있다(3). 하지만, 전복 내장으로부터 분리된 수용 성 황함유 다당체는 라디칼 소거능이 우수하였으며(33), $\operatorname{Lim}(5)$ 은 전복 추출물이 인체 섬유육종세포(HT-1080)에서 $\mathrm{H}_{2} \mathrm{O}_{2}$ 처리에 의한 활성산소종의 생성을 억제시키는데 효과 가 있어, 이는 전복의 먹이가 되는 해조류인 갈조류 중 탄닌 계 지용성 항산화 물질과 홍조류의 페놀 화합물 등(34)에
기인된 것으로 보고한 바 있다. 또한 전복 추출물이 $\mathrm{ACE}$ 저해능 및 항혈전능에 효과적이라는 보고(3), 복분자 및 구기자의 우수한 항산화 활성 $(35,36)$, 이들 식물류의 체내 지질 개선 효과 $(37,38)$ 등이 알려져 있는 바, 본 연구에서 전복 복합물의 체내 지질과산화물의 생성억제 및 항산화능 은 이들 시료의 활성과 관련성이 높다고 생각된다.

과도한 신체활동에 의한 피로는 근력의 저하 뿐 아니라 자기 조절능력의 감소와 무기력증을 초래하기도 한다. 신 체 활동의 강도와 시간에 따라 근육 피로는 상이하나, 기능 성 식품의 섭취로 인하여 체내 피로를 감소시킬 수 있다는 여러 연구보고로 볼 때( $20,21,24)$, 본 연구 결과 전복 복합물 의 섭취는 운동 뿐만 아니라 일상생활로부터 초래되는 스트 레스에 대해서도 생체 내 항산화 및 피로 회복에 도움이 될 것으로 기대된다.

\section{요 약}

전복 음료를 개발하기 위하여 전복에 식물류를 혼합한 전복 복합물의 in vitro 항산화능을 측정하였으며, 정상군, 대조군, 전복 복합물의 성인 1 일 1 회분(APM-1) 급이군 (EAPM-1) 및 3회분(APM-2) 급이군(EAPM-2)으로 구분하 여 4주간 실험사육하였다. 전복 복합물의 in vitro 항산화능 과 총 페놀 및 플라보노이드 함량은 APM-2가 유의적으로 높았다. 혈중 총 지질 함량은 대조군에 비해 운동과 전복 복합물을 병행급이한 EAPM-2군이 유의적으로 감소되었 다. $\mathrm{LDH}$ 활성 및 $\mathrm{BUN}$ 함량은 대조군에 비해 전복 복합물 급이군에서 유의적으로 감소되었다. AST 활성은 전복 복합 물 급이 시 대조군과 유의차가 없었으며, ALT 및 ALP 활성 은 대조군에 비해 유의적으로 감소되었다. 혈청 및 간 조직 에서 지질과산화물 함량은 대조군에 비해 전복 복합물 급이 군에서 유의적으로 감소하였다. 간 조직의 라디칼 소거능 은 대조군에 비해 전복 복합물의 급이 시 유의적으로 증가 하였다. 따라서 전복 복합물은 항산화능 및 페놀 화합물에

Table 7. TBARS content and DPPH radical scavenging activity in serum and liver tissue of the rats supplemented abalone composites

\begin{tabular}{|c|c|c|c|c|}
\hline Groups $^{1)}$ & Normal & Control & EAPM-1 & EAPM-2 \\
\hline \multicolumn{5}{|l|}{ TBARS content } \\
\hline Serum (mmol/mL) & $61.04 \pm 11.18^{\mathrm{a} 2)}$ & $73.88 \pm 4.28^{\mathrm{b}}$ & $61.16 \pm 4.1^{3 \mathrm{a}}$ & $58.44 \pm 2.06^{\mathrm{a}}$ \\
\hline Liver $(\mathrm{mmol} / \mathrm{g})$ & $259.56 \pm 51.59^{a b}$ & $314.37 \pm 55.96^{\mathrm{b}}$ & $222.52 \pm 41.39^{\mathrm{a}}$ & $281.41 \pm 18.56^{b}$ \\
\hline \multicolumn{5}{|c|}{ DPPH radical scavenging activity (\%) } \\
\hline Serum & $90.82 \pm 1.52^{\mathrm{NS}}$ & $87.31 \pm 5.14$ & $87.32 \pm 1.12$ & $90.30 \pm 0.62$ \\
\hline Liver & $83.83 \pm 3.16^{\mathrm{ab}}$ & $80.90 \pm 4.04^{\mathrm{a}}$ & $88.59 \pm 1.21^{\mathrm{c}}$ & $85.80 \pm 0.89^{b c}$ \\
\hline
\end{tabular}

\footnotetext{
${ }^{1)}$ Normal, non exercised group; Control, exercised group by running on the treadmill; EAPM-1, exercised group by running and APM-1 supplementation; EAPM-2, exercised group by running and APM-2 supplementation.

${ }^{2)}$ Values are mean $\pm \mathrm{SD}(\mathrm{n}=6)$.

${ }^{\text {act }}$ Values in a column sharing the same superscript letter are not significantly different at $p<0.05$

${ }^{\mathrm{NS}}$ Not significant.
} 
의존하여 트레드밀 운동에 의한 산화적 스트레스 해소 및 피로 회복 에 도움이 될 것으로 예상된다.

\section{감사의 글}

본 연구는 2014년도 산학연 공동기술개발사업에 의하여 수행된 결과의 일부이며, 지원에 감사드립니다.

\section{References}

1. Shin JH, Choi DJ, Lee SJ, Cha JY, Sung NJ (2008) Antioxidant activity of black garlic (Allium sativum L.). J Korean Soc Food Sci Nutr, 37, 965-971

2. Kumar CT, Reddy VK, Thyagarajuk PM, Reddanna PP (1992) Dietary supplementation of vitamin E products heart tissue exercise induced oxidant stress. Mol Cell Biochem, 111, 109-115

3. Kim HL, Kang SG, Kim IC, Kim SJ, Kim DW, Ma SJ, Gao T, Li H, Kim MJ, Lee TH, Ham KS (2006) In vitro anti-hypertensive, antioxidant and anticoagulant activities of extracts from Haliotis discus hannai. J Korean Soc Food Sci Nutr, 35, 835-840

4. Koh SM, Kim HS, Cho YC, Kang SG, Kim JM (2009) Preparation and physicochemical characteristics of abalone meat aged in Kochujang. J Korean Soc Food Sci Nutr, 38, 773-779

5. Lim SY (2014) Cytotoxic and antioxidant activities abalone (Haliotos discus hannai) extracts. J Life Sci, 24, 737-742

6. Shin JH, Lee SJ, Choi DJ, Kang MJ, Sung NJ (2008) Antioxidant and alcohol dehydrogenase activity of water extracts from abalone containing medicinal plants. Korean J Food Cookery Sci, 24, 182-187

7. Blois MS (1958) Antioxidant determination by the use of a stable free radical. Nature, 181, 1199-1200

8. Re R, Pellegrini N, Proteggente A, Pannala A, Yang M, Rice-Evans C (1999) Antioxidant activity applying an improved ABTs radical cation decolorization assay. Free Radic Biol Med, 26, 1231-1237

9. Benzie IFF, Strain JJ (1996) The ferric reducing ability of plasma (FRAP) as a measure of "antioxidant power" : the FRAP assay. Anal Biochem, 230, 70-79

10. Gutfinger T (1981) Polyphenols in olive oil. J Am Oil Chem Soc, 58, 966-968

11. Moreno MIN, Isla MI, Sanpietro AR, Vattuone MA
(2000) Comparison of the free radical scavenging activity of propolis from several region of Argentina. J Enthnopharmacol, 71, 109-114

12. Frings CS, Fendley TW, Dunn RT, Queen CA (1972) Improved determination of total serum lipids by the sulfo-phospho-vanillin reaction. Clin Chem, 18, 763-764

13. Friedewald WT, Levy RI, Fredrickson DS (1972) Estimation of the concentration of low density lipoprotein cholesterol in plasma, without use of the preparative ultracentrifuge. Clin Chem, 18, 499-502

14. Yagi K (1984) Assay for blood plasma or serum. In : Method in Enzymology, Packer L (Editor), Academic Press, Inc., NY, USA, p 328-331

15. Uchiyama M, Mihara M (1978) Determination of malondialdehyde precursor in tissues by TBA test. Anal Biochem, 86, 271-278

16. Lim BO, Seo TW, Shin HM, Park DK, Kim SU, Cho $\mathrm{KH}$, Kim HC (2000) Effect of Betulae platyphyllae cortex on free radical in diabetic rats induced by streptozotocin. Korean J Herbology, 15, 69-77

17. Cho HS, Lee SJ, Shin JH, Kang MJ, Cho HS, Lee HJ, Sung NJ (2007) Antioxidative activity and nitrite scavenging effect of the composites containing medicinal plant extracts. J Life Sci, 17, 1135-1140

18. Lee JM, Lee SH, Kim HM (2000) Use of Oriental herbs as medical food. Food Ind Nutr, 5, 50-56

19. Na CS, Kim HK, Kim JB, Roh HJ, Um NN, Noh HJ, $\mathrm{Na}$ DS, Dong MS, Hong CY (2013) The effects of Hovenia dulcis fruit hot water extracts on anti-fatigue and improvement of the exercise performance in SD rats. Yakkak Hoeji, 57, 348-356

20. Kang JR, Lee SJ, Hwang CR, Kim IS, Sung NJ (2013) Effect of black garlic and Gaeddongssuk (Artemisia annua L.) extracts on the lipid profile and hepatic antioxidant enzyme activities of exercised rats. J Korean Soc Food Sci Nutr, 42, 869-876

21. Kang MJ, Shin JH, Sung NJ (2011) Recovery effect of garlic extract and vitamin B group enhanced diet on swimming fatigue. J Life Sci, 21, 875-883

22. Na CS, Hong CY, Na DS, Kim JB, Yoon SY, Lee SB, Dong MS (2013) Hot water extract of Hovenia dulcis peduncle improves exercise performance and anti-fatigue effect in rats. Korean J Pharmacogn, 44, 83-90

23. Kim YJ, Jung UJ, Lee GD, Choi MS (2012) Effects of herbal sports drinks containing Prunus mume fruit extract on the plasma lipid profile and endurance of rats. J Korean Soc Food Sci Nutr, 41, 1409-1416 
24. Lee SJ, Kim IS, Lee HJ, Oh SJ, Shin JH, Kim JG, Sung NJ (2013) Effect of black garlic and herb formulas in lipid profiles and antioxidant status in rats by interval running training. J Life Sci, 23, 1436-1444

25. Song TC, Han D, Lee CH, Kim YE, Jung KA, Kim HY (2005) Effect of dietary supplementation of two tonic formula on the forced-swimming capacity of rats. Korean J Food Sci Technol, 37, 648-655

26. Agner E, Kelbaek H, Fogh-Anderson N, Morck HI (1988) Coronary and skeletal muscle enzyme change during a $14 \mathrm{~km}$ run. Acta Med Scand, 224, 183-186

27. Kim SM, Ko JH, Shim EJ, Lee DH, Cho DJ, Kim DH, Min KS, Yoo KY (2008) Serum creatinine, blood urea nitrogen change in low birth weight infants during their first days of life. Korean J Perinatol, 19, 181-189

28. Kang YJ, Kim HJ, Han JS (2011) Effects of Ishige okamurae extract supplement on blood glucose and antioxidant systems in type 2 diabetic patients. J Korean Soc Food Sci Nutr, 40, 1726-1733

29. Kim YS, Ryu BH, Kim JS (2009) Effect of Wongisaengmaek-san extract on antioxidative and anti-fatigue activity. Korean J Orient Int Med, 30, 94-106

30. Kwon TD, Ryu SP, Jang WC, Lee SC (2002) Effects of green tea polyphenol ingestion on blood lipids, MDA and SOD in rats. Korean J Exercise Nutr, 6, 85-88

31. Kim SH, Baek YH (2011) Effects of aerobic exercise and black garlic intake on blood lipids, lipid peroxidation and BAP in rats. J Life Sci, 21, 1025-1031
32. Haenen GR, Paquay JB, Korthouwer RE, Bast A (1997) Peroxynitrite scavenging by flavonoids. Biochem Bioph Res Co, 236, 591-593

33. Zhu BW, Wang LS, Zhou DY, Li DM, Sun LM, Yang JF, Wu HT, Zhou XQ, Tada M (2008) Antioxidant activity of sulphated polysaccharide conjugated from abalone (Haliotos discus hannai Ino). Euro Food Res Technol, 22, 827-832

34. Jimemez-Escrig A, Goni Cambrodon I (1999) Nutritional evaluation and physiological effects of edible seaweeds. Arch Latinoam Nutr, 49, 114-120

35. Kwon JW, Lee HK, Park HJ, Song JY (2012) Physiological activities of Rubus coreanus Miq. extracts using different extraction methods. Korean J Food Cookery Sci, 28, 25-32

36. Shon HK, Lee YS, Park YH, Kim MJ, Lee KA (2008) Physico-chemical properties of Gugija (Lyciifructus) extracts. J Food Cookery Sci, 24, 905-911

37. Hwang EY, Hong JH, Choi JH, Lee EJ, Lee IS (2009) Study on anti-obesity and hypoglycemic effects of Lycium chinense Mill extracts. J Korean Soc Food Sci Nutr, 38, 1528-1534

38. Jung MA, Cho SH, Lee SY, Kim JH, Oh KN, Kim YS, Yoo GS, Lee DW, Kim SO (2014) Effects of unripe Rubus coreanus Miquel extract on improvement of lipid metabolism in C57BL/6 mice fed a high-cholesterol diet. J Korean Soc Food Sci Nutr, 43, 650-655 